Ingy, Vol. 1, p. 149, Academic Press, New York (1955); 7) Lowry, O.H., Rosebrough, N.J., Farr, A.L. and Randall, R.J.: J. biol. Chem. 193, 265 (1951); 8) Yamamoio, I., Inoki, R., Kolma, S. and Tamari, Y.: Japan. J. Pharmacol. 21, 13 (1971); 9) Fillion, G.M.B., Lduch, S. and Uvinas, B.: Acta physiol scamd. 83, 115 (1971); 10) Berridgy, M.J. and Patel, N.G.: Science 162, 462 (1968); 11) Scias, L.F., Westerman, C.D., Berdesca, A.S. and Hilton, J.G.: Am. J. Physiol. 199, 867 (1960); 12) Sarcione, E.J., Back, N., Socal, J.E., Melllman, B. A^D KNOBLOCK, E.: Endoclinology 72, 523 (1963)

\title{
SPECIFIC PRESSOR ACTIVITY OF ANGIOTENSINS I AND II
}

\author{
Terumi NAKAJIMA, Shumpei SAKAKIBARA, Akira SAKUMA \\ and Hirofumi SOKABE \\ Institutes of Pharmaceutical Sciences, Hiroshima University School of Medicine, \\ Hiroshima: Peptide Institute, Protein Research Foundation, Minoh; Department \\ of Pharmacology, Institute for Cardiovascular Diseases, School of Medicine, \\ Tokyo Medical and Dental University, Tokyo; and Department of \\ Pharmacology, Toho University School of Medicine, Tokyo
}

Accepted April 11, 1973

It is generally accepted that the biological aclivity of 5-isoleucine- and 5-valine-angiotensin II is equal even when aspartic acid in position 1 is substituted by asparagine (1). Angiotensin I has approx. one third the pressor activity of angiotensin II (1). However, a survey of literature reveals cerlain inconsistencies $(2-10)$ (Table 1).

We synthesized Asp ${ }^{1}-I e^{5}$-angiotensin I and II by the classical procedures (11), and purified them by SE-Sephadex column chromatography (12). We also purified Asn ${ }^{1}$ Val"-angiotensin II (Ciba Lol-171671). Purity of these angiotensins was checked after dansylation (13). They showed single spots on a thin-layer chromalogram of Silica gel H. Their weights were determined by oplical density of tyrosine (OD 275) on approx. $10 \mathrm{mg}$ of the pure samples.

A four-point assay was performed on various combinations of angiotensins I or II in 6 rats, injecting each with four of low and high doses. Female rats of the Donryu strain, weighing $200 \div 20 \mathrm{~g}$, were anesthetized with pentobarbital sodium $(50 \mathrm{mg} / \mathrm{kg}$, i.p.) and treated with pentolinium tartrate $(5 \mathrm{mg} / \mathrm{kg}$, i.v.). The femoral artery and vein were cannulated for blood pressure registration and intravenous injection respectively.

Angiolensins were dissolved in $0.3 \mathrm{ml}$ of $0.9 \% \mathrm{NaCl}$ containing $0.001 \%(\mathrm{v} / \mathrm{v})$ of Tween 20. Low and high doses were 1 or 2 and 10 or $20 \mathrm{ng}$ respectively. These doses had been determined in preliminary experiments, in which 0.2 to $40 \mathrm{ng}$ of angiotensins were used to examine linearity and parallelism in dose-response curves of two samples.

The data were analyzed statistically by the routine $2 \times 2$ parallel line assay (14) (Table 2). We found that the pressor activity of Asn ${ }^{1}$-Val' ${ }^{1}$-angiotensin II and Asp ${ }^{1}-I l e^{1}$-angiotensin II was not equal in the rat, suggesting that native angiotensin (13) is more potent. 
TABIF 1. Specific pressor aclivity of angiotensins I and II

\begin{tabular}{|c|c|c|c|}
\hline Angiotensin & $\begin{array}{l}\text { Sp. activity in } \\
\text { weight }(0 / 0)\end{array}$ & $\begin{array}{l}\text { Assity } \\
\text { animal }\end{array}$ & Reference \\
\hline Asp ${ }^{1}-11 \mathrm{e}^{5}-$ Ang & 100 & rat & Gross \& Turrian, 1960 (2) \\
\hline$A s p^{1}-V a 1^{5}-A n g 11$ & 100 & & \\
\hline Asn ${ }^{1}-I^{5}$-Ang II & 100 & & \\
\hline$\Delta \sin ^{1}-\mathrm{Va}^{5} \mathbf{l}^{5}$-Ang II & 100 & & \\
\hline$A s p^{1}-Y_{a l} l^{5}$-Ang II & 100 & rat & Paiva \& Paiva, $1960(3,4)$ \\
\hline Asn ${ }^{1}-V_{a} l^{5}-A n g$ II & $53-4$ & & \\
\hline Asn $-I l e^{5}-$ Ang II & $28=4$ & & \\
\hline Asp ${ }^{1}-\mathrm{Il}^{3}$-Ang & 100 & rat & Bumpus et al, 1961 (5) \\
\hline Asp $^{1}-\left[\mathrm{le}^{5}-\mathrm{Ang} \quad \mathrm{I}\right.$ & 86 & & \\
\hline Asn ${ }^{1}-I^{5}-A n g$ II & 85 & & \\
\hline $\mathrm{Asn}^{1}-\mathrm{VaI}^{5}$-Ang II & 100 & $\mathrm{rat}$ & Guttmann, 1961 \\
\hline Asp'-Val'-Ang I & 89 & & \\
\hline Asp ${ }^{1}-I^{5}-$ Ang II & 100 & ral & Page \& Bumpus, 1961 (1) \\
\hline $\mathrm{Asp}^{1}$-Val - Ang II & 100 & & \\
\hline Asn ${ }^{1}-I^{5}-A n g \quad$ II & 100 & & \\
\hline $\operatorname{Asn}^{1}-V_{a l^{5}}$-Ang II & 100 & & \\
\hline Asp ${ }^{1}-1 e^{5}-$ Ang I & 52 & & \\
\hline Asp $p^{1}-I e^{5}-$ Ang II & 100 & cat & Helner, $1964(7)$ \\
\hline$A s p^{1}-V_{a} l^{5}-A n g$ II & 100 & & \\
\hline$A s n^{1}-V a l^{5}-A n g$ II & 100 & & \\
\hline Asp - Ile $^{5}-$ Ang II & 100 & rat & Gould, Skeggs \& Kahn, 1966 \\
\hline$A s n^{1}-V a l^{5}-A n g$ II & 57 & & \\
\hline Asp $p^{1}-11 e^{5}-$ Ang $\quad I$ & 60 & & \\
\hline$A s n^{1}-V a 1^{5}-A n g$ II & 100 & rat & Boyd et al., 1969 (9) \\
\hline Asn'-Val ${ }^{5}-$ Ang $I$ & 60 & & \\
\hline Asn'-Val ${ }^{5}-A n g$ II & 100 & rat & Kreye \& Gross, 1971 (10) \\
\hline Asn'-Val'-Ang I & 58 & & \\
\hline$\Lambda s p^{1}-I l e^{5}-\wedge n g \quad I$ & 45 & & \\
\hline Asp'-Ile'-Ang II & 100 & rat & Arakawa, \\
\hline Asp $p^{1}-11 e^{5}-A n g$ & $55(45-75)$ & & (personal communication) \\
\hline
\end{tabular}

$\frac{\text { TABM 2. Specific pressor activity of angiotensins in the rat by 4-point assay }}{\mathrm{T}}$

\begin{tabular}{|c|c|c|c|}
\hline Asp $111 e^{5}$-Ang I & $\begin{array}{l}\text { Asn'-Val }{ }^{5}-A n g \text { II } \\
(\mathrm{Ciba} \text { Lot-051640) }\end{array}$ & $\begin{array}{c}0.904 \\
(0.845-0.968)\end{array}$ & $\begin{array}{c}1.136 \\
(1.062-1.217)\end{array}$ \\
\hline Asp'-Ilki-Ang $I$ & $\begin{array}{l}\text { A } \operatorname{sn}^{1}-\mathrm{Val}^{3}-\mathrm{Ang} \text { II } \\
\text { (Ciba Lot-171671) }\end{array}$ & $\begin{array}{c}0.716 \\
(0.678-0.757)\end{array}$ & $\begin{array}{c}0.900 \\
(0.852-0.952)\end{array}$ \\
\hline Asp'-lle ${ }^{5}$-Ang II & $\begin{array}{l}\text { Asn } 1^{1}-\mathrm{Val}^{5}-\mathrm{Ang} \text { II } \\
(\mathrm{Ciba} L \mathrm{~L}-171671)\end{array}$ & $\begin{array}{c}1.290 \\
(1.235-1.347)\end{array}$ & $\begin{array}{c}1.309 \\
(1.254-1.367)\end{array}$ \\
\hline Asp ${ }^{1}-\mathrm{Ile}^{5}$-Ang 1 & $A s p^{2}-l k^{5}-A n g \quad$ II & $\begin{array}{c}0.510 \\
(0.488 \quad 0.532)\end{array}$ & $(0.605-0.659)$ \\
\hline Asn'-Val'-Ang II & $\begin{array}{l}\text { Asn }-\mathrm{Val}^{5} \text {-Ang II } \\
\text { (Ciba Lot-171671) }\end{array}$ & $\begin{array}{c}0.951 \\
(0.893-1.014)\end{array}$ & $\begin{array}{c}0.951 \\
(0.893-1.014)\end{array}$ \\
\hline
\end{tabular}

$\mathrm{T}$ : test material, $\mathrm{S}$ : standard material, $\mathrm{PR}_{W}$ : potency ratio on a wt. basis, $\mathrm{PR}_{\mathrm{M}}$ : potency ratio on a molar basis. The $95 \%$ confidence interval is in parentheses. 
The potency ratio of $\mathrm{Asp}^{1}-1 \mathrm{cc}^{5}$-angiolensin I relative to $\mathrm{Asp}^{1}-\mathrm{Ile} \mathrm{e}^{5}$-angiotensin II was 0.51 un a weight basis, or 0.63 on a molar basis, which accords with previously reported data (1).

Acknowledgments: We thank Mrs. Mituko Sokabe, and Mrs. Misuzu Arai for technical assistance.

\title{
REFERENCES
}

1) Page, I.H. and Bumpus, F.M.: Physiol. Rev. 41, 331 (1961); 2) Gross, F. and Turrian, H.: Polypeptides which Affect Smooth Muscles and Blood Vessels, Edited by Schachter, M., p. 137, Pergamon, New York (1960); 3) PaIVA, A.C.M. And PaIva, T.B.: Biochem. Pharmacol. 5, 187 (1960); 4) Paiva, T.B. ANd Paiva, A.C.A.: Br. J. Pharmacol. Chemother. 15, 557 (1960); 5) Bumpus, F.M., Khairalla, P.A., Arakawa, K., Pagf, I.H. and Smeby, R.R.: Biochim. hiophys. Acta 46, 38 (1961); 6) Guttmann, S.: Helv. chim. Acta 44, 721 (1961); 7) Helmer, O.M.: Am. J. Physiol. 207, 368 (1964); 8) Gould, A.B., Skeggs, L.T. and Kailn, J.R.: Lab. Invest. 15, 1802 (1966); 9) Boyd, G.W., Adamson, A.R., Fitz, A.E. ANd PEART, W.S.: Lancet 1 (7588), 213 (1969); 10) KreYe, V.A.W. AND Gross, F.: Am. J. Physiol. 220, 1294 (1971); 11) Okada, Y., Yoshimura, S., Shudo, K. and Sakakibra, S.: (in preparation); 12) NakaJima, T., Nakayama, T. and Sokabe, H.: Gen. comp. Endocrinol. 17, $458(1971)$; 13) Nakayama, T., Nakajima, T. And Sokabe, H.: Chem. Pharm. Bull. 20, 1579 (1972); 14) Finvey, D.J.: Statistical Method in Biological Assay, Charles Griffin, London, (1952)

\section{MORPHINE SPECIFIC SEIZURE INDUCED IN POLY-D-LYSINE PRETREATED MICE AND SOME EVIDENCE SUGGESTING THE PRESENCE OF A NOVEL SITE FOR THE MORPHINE EFFECT}

\author{
Masao KOIDA, Shigeru MURAOKA, Masakatsu TAKAHASHI \\ and Hiroshi KANETO \\ Department of Pharmacology, Faculty of Pharmaceutical Sciences, \\ Nagasaki University, Bunkyo-machi, Nagasaki, Japan
}

Accepted May 1, 1973

While studying the pharmacological properties of a morphine derivative covalently bound to the macromolecules, it was noticed that the mice, after being intracranially pretrealed with poly-D-lysine carrying the morphine derivative, responded to the s.c. injected dose of morphine in an unusual manner (1). A peculiar type of seizure, like the one inducible by strychnine, occurred and the animals died. The phenomenon was obscrved to similarly occur in mice pretreated with poly-D-lysine.

In the solution of physiological $\mathrm{pH}$, the polymer cxists as a strongly charged polycationic molecule and then, when such a molecule comes into contact with the ccll membrane, the easily conceivable consequence would be that the functions of the cell would more or less be inevitably modified $(2-7)$. From this viewpoint, the above described ob- 